\title{
REVIEW OF NANOPARTICLES SYNTHESIS TECHNIQUES \& ITS APPLICATION FIELDS
}

\author{
Jyoti Kumari ${ }^{1}$
}

Abstract-Nanoparticles attract huge attention recently in various research fields including physics, chemistry, mechanical \& electrical engineering, material science. These nanoparticles are small sized particles whose range lies between 1-100 $\mathrm{nm}$. These are most studied \& developed because of their wonderful application in almost every field of life. Different type of nanoparticles contribute different functions \& these applications are reviewed. Recent article focused on introduction, synthesis methods and application of Nanoparticles.

Keywords- Nanoparticle, Approach, synthesis, application, Nanotechnology

\section{INTRODUCTION}

Nanotechnology is the branch of science which deals with matter at nanoscale $1 \mathrm{~nm}=10^{-9} \mathrm{~m}$. Nanotechnology is not a new term for this modern world. However, it has been used in past time in pottery \& medicine. For instance- silver and gold particles were used in pottery to show different colors (optical property). In present time, nanoscience becomes an area of intense scientific research due to its enormous applications in diverse fields Nanotechnology deals with manipulation at atomic or molecular level.

Richard flyman talked about this is year 1959 which become basis for foundation of nanotechnology Nanoparticles Nanoparticles are very small size particles with a diameter range between 1-100 $\mathrm{nm}$. Because of their large surface area to volume ratio, nanoparticles show special properties \& these properties are different with respect to bulk material Nanoparticles acts as a bridge between bulk material \& atomic or molecular level. Nanoparticles have special properties compared to bulk material. for instance - copper nanoparticles of dimension less than $50 \mathrm{~nm}$ is known as super hard material that differ from ductile and malleable properties of bulk material. These particles possess physical properties such as uniformity, conductance or special optical property which make them ideal for use in medical

$\&$ material science. Nanoparticle is the most fundamental factor in the manufacturing of nanostructure. It is much smaller than everyday object that follow newton's low of motion but bigger than atom or molecule governed by quantum mechanics.

\section{CLASSIFICATION}

There can be different types of nanoparticles like silver and gold nanoparticle, TiO2 nanoparticle, fine \& ultrafine particulate matter in air, and many others. Broadly, Nanoparticle can be divided into 2 categories,

1. Organic nanoparticle 2. Inorganic nanoparticle

Organic nanoparticles are carbon nanoparticles and inorganic nanoparticles include magnetic, semiconductor and metallic nanoparticle. Physical and chemical properties of metallic nanoparticles are different from bulk metals. Example - lower melting point, specific optical properties, specific magnetization, higher specific surface area \& mechanical strength.

\section{PROPERTIES OF NANOPARTICLES}

Nanoparticles have a very high surface area to volume ratio, which provides a great driving force for diffusion particularly at high temperature. Properties of nanoparticle start changing when we reach at nano level. Nanoparticles show different colors from different directions. This is due to their mobility to lock their electron at fixed point. For instance gold nanoparticles look red to black color in solution. Biological systems like cells or tissues react differently to nanoparticles than to bulk material. This property increases its use in medical science.

\section{SYNTHESIS OF NANOPARTICLES}

There are two major approaches by which we can manufacture nanoparticles. These are top down and bottom up approach. Top down - It includes decomposition of larger particles into nanoparticles. Typical examples are etching through the mask ball milling \& application of plastic deformation. This is slow process and not suitable for large scale production and by nature, it is not cheap \& quick to man faction Bottom up: - Assembly of nanoparticles from molecules or atoms: The chemical approach/Chemical Reduction method -

\footnotetext{
${ }^{1}$ Kurukshetra University, Kurukshetra, Haryana, India
} 
A. Polyol - Silver nanoparticles are prepared by this method. Organic acid, sodium borohydride, sugar sodium borohydride [NaBH4], hydrazine hydrate and sodium citrate are some of the commonly used reducing agents in which the ionic salt gets involved in reduction process. A chemical reaction that leads to a solid phase is carried out by rapidly mixing suitable reagents.

$\mathrm{Ag}^{+}+$reducing agent $\longrightarrow \longrightarrow$ Ago

$\mathrm{Cd}^{2+}+\mathrm{Se}^{2-} \longrightarrow \longrightarrow \mathrm{CdSe}$

\section{INERT GAS CONDENSATION}

There is an ultra high vacuum chamber filled with He or Argon gas at typical pressure of around 100 pascals where different metals are evaporated inside separate crucibles. Due to collision between atoms evaporated metal atoms lose their kinetic energy and condensed in the form of small crystals which accumulate on liquid nitrogen boiled cold finger. Example - Gold nanoparticles have been synthesized from gold wires.

\section{SOL-GEL TECHNIQUE}

In this technique discrete particles are integrated network precursor involved in chemical solution that is mainly used for the manufacture of metal oxides. The precursor sol can be either used to synthesize powder or deposited on the substrate to form a film. Colloidal particles involve the generation of network through sol formation \& gelatin to from network in liquid phase called as gel. The precursors for synthesizing colloids consist of metal alkoxides ion \& alkoxysilane. The most widely used are tetraethoxysilane (TEOS) and tetramethoxy silence which form silica gel. The sol gel process involves initially homogenous sol of one or more selected alkoxides. These are organic precursors for silica, alumina, titania \& zirconium Alkoxide which are immiscible in water, are organ metallic precursor for silica, aluminium, titanium and zirconium. A catalyst is used to start reaction \& control pH. Sol. Gel formation occurs in 4 stages.

\section{SOL-GEL METHOD}

Sol-Gel is chemical solution process used to make glass \& ceramic material in the form of fibers, thin films or powders. A sol is colloidal or suspension of solid particles of ions in a solvent gelatin network in liquid state (gel). The precursors for synthesizing collides contain ions of metal alkoxides \& alkoxysilane. The sol-gel process is a wet chemical technique to produce an integrated network (gel) either by using chemical solution or by colloidal particles. Metal alkoxides \& chloride undergo hydrolysis \& condensation reaction to form a colloid, a system composed of nanoparticle dispersed in solvent. Sol get formation occurs in 4 stages

Hydrolysis:- There is replacement of or group by $\mathrm{OH}$ group with addition of water

$\mathrm{M}-\mathrm{OR}+\mathrm{HOH} \longrightarrow \mathrm{MOH}+\mathrm{ROH}$

$\mathrm{M}=$ SILICON

Hydrolysis process can be accelerated by addition of catalyst such as $\mathrm{HCl}, \mathrm{NH} 3$.

(a) Condensation:- Condensation reaction occurs between two silanol group to produce siloxane bond and alcohol \& water are side product

$\mathrm{SIOH}+\mathrm{HO}-\mathrm{SI} \longrightarrow \mathrm{SI}-\mathrm{O}-\mathrm{SI}+\mathrm{H} 2 \mathrm{O}$

$\mathrm{SI}-\mathrm{OR}+\mathrm{SIOH} \longrightarrow \mathrm{SI}-\mathrm{O}-\mathrm{SI}+\mathrm{ROH}$

The hydrolysis rate constant is affected by $\mathrm{pH}$, reagent concentration and $\mathrm{H} 2 \mathrm{O} /$ similar ratio.

(b) Growth and agglomeration :-As the no. of siloxane bond increase, the molecule aggregate in solution, when they form a network, a gel is formed upon drying. The water and alcohol are eliminated \& network shrinks.
$2 \mathrm{HO} \mathrm{Si}(\mathrm{OR})_{3}$
$(\mathrm{OR})_{3} \mathrm{SI}-\mathrm{O}-\mathrm{SI}(\mathrm{OR})_{3}+\mathrm{H} 2 \mathrm{O}$
(OR)
$3 \mathrm{SiOR}+\mathrm{HO} \mathrm{SI}(\mathrm{OR})_{3} \longrightarrow(\mathrm{OR})_{3}-\mathrm{SI}-\mathrm{O}-\mathrm{Si}-(\mathrm{OR})_{3}+\mathrm{ROH}$

The most widely used precursors are tetramethoxysilane and tetra ethoxysilane which form silica gel. Alkoxides, immiscible in water are organo-metallic precursors for silica, aluminium, titanium, zirconium alcohol is used as solvent.

\section{SOLVOTHERMAL PROCESS}

In this process, polar solvent are heated at temperature above their boiling points and at very low temperature according to the pressure applied in a closed system. Solvothermal process is used for preparing conductors ceramics $\&$ polymers. The process can be used to prepare many geometry including thin films, single crystal and nano crystals.

Solution phased oxidation - Reduction method - Formation of si nanoparticle

$\mathrm{SiCi}_{4}+15 \mathrm{Na}+$ Glyme+N${ }_{2} \mathrm{~atm}------->\mathrm{SI}-\mathrm{CI}+15 \mathrm{NaCl}$ 
$\mathrm{Mg}_{2} \mathrm{Si}+2.5 \mathrm{M} \mathrm{Br}_{2}$ +octane-------> $\mathrm{Si}-\mathrm{Br}+2 \mathrm{M} \mathrm{MgBr}_{2}$

Preparations of Silicon carbide by chemical reaction involve direct interaction of $\mathrm{Si}$ with $\mathrm{C}$ produce sic nanoparticles.

$\begin{array}{ll}2 \mathrm{C}+\mathrm{O}_{2} \longrightarrow & 2 \mathrm{CO} \\ 2 \mathrm{Si}+\mathrm{O}_{2} \longrightarrow & 2 \mathrm{SiO} \\ \mathrm{SiO}+2 \mathrm{C} & \mathrm{CiC}+\mathrm{CO} \\ \mathrm{SiO}+\mathrm{CO} \longrightarrow & \mathrm{SiC}+\mathrm{O}_{2} \\ \mathrm{CO}+\mathrm{C} \longrightarrow & \mathrm{C} \mathrm{CO} \\ \mathrm{SiO}+\mathrm{CO} \longrightarrow \mathrm{SiC}+\mathrm{SiO}\end{array}$

\section{APPLICATION OF NANOPARTICLES}

Nanoparticles are of great use in very field. As these particles deals at nano level, so they can introduced at very small unit in human body and can get desired result. So it is very useful in different properties and these properties are used in material science, manufacturing, environmental science, everyday objects like beauty products, sunscreen.

\section{NANOPARTICLE \& ENVIRONMENT}

Nanoparticles are efficiently using in cleaning environmental pollution. For instance - photocatalyst copper tungsten oxide nanoparticle has been used to break down oil into biodegradable compounds. Nanoparticles having high surface area are activated by sunlight $\&$ this work in water making them useful for cleaning up oil spill. Researchers are using gold nanoparticles enclosed in a porous manganese oxide to breakdown volatile organic pollutants. Carbon tetrachloride (CCl4) in ground water is clean up iron nanoparticles. Iron oxide nanoparticle are used to clean arsenic from water wells.

\section{NANOPARTICLES \& WATER TREATMENT}

Water pollution caused by industrial, municipal and agricultural activities becomes a great concern. To meet this challenge, nanoparticles can provide good solution. Nanoparticles are playing an important role in improving the water supply system \& developing the next generation of sustainable water treatment system due to their unique features like large surface area, small size, catalytic and antimicrobial potential, high efficiency and high flexibility. Nanoparticles have been used in procedures such as decontamination, fouling control, disinfection, groundwater remediation, quality control and seawater reverse osmosis.

\section{NANOCATALYST}

Because of their high surface to volume ratio, selectivity activity easy separation, these nanoparticles may serve as heterogenous catalyst \& it supports gas \& liquid phase. The most used nanoparticles are gold, silver, copper, paladium, platinum, Nickel \& TiO2. Graphene quantum dots are noted as excellent metal free catalyst for oxygen reduction reaction. Nanoparticles are being used in selective oxidation \& reduction reaction.

Iron nanoparticles are being used for sustainable production of lower olefines which are key unit in integration in polymer, drugs and cosmetics. Solar driven photocatalyst has many application in energy efficiency \& environmental application such as waste water treatment, air purification, energy efficient buildings. Current challenges of nanocatalyst include

(a) Improving the selectivity and efficiency of reaction.

(b) Improving recyclability and recovery of the catalytic materials.

\section{NANOPARTICLES IN CONSTRUCTION INDUSTRY}

Construction industry use nanoparticle for enhanced properties which can increase strength \& durability of construction materials. For example addition of $105 \mathrm{wt} \%$ of 10-25 mm ZrO2, Fe3O4 or Al2O3 in concrete can increase the compressive strength by $25-75 \%$ \& reduce the chloride penetration thus increasing the durability. $\mathrm{TiO} 2$ is a common photocatalyst, due to its high efficiency high stability \& low cost, it is introduced into paints \& cement can promote pollutant decomposition. TiO2 coated walls have self cleaning \& self cooling property. Nanoparticles such as $\mathrm{SiO} 3, \mathrm{Al} 2 \mathrm{O} 3, \mathrm{CeO} 2$ added to steel can increase corrosion resistant property. $\mathrm{SiO} 2, \mathrm{ZnO}$ nanoparticles when added to wood glass \& ceramics make them fire resistant. Besides number of benefits, construction industry is offset to use nanoparticles because of their high cost and safety concern. Further research is needed to overcome these problems.

\section{NANOPARTICLES IN MANUFACTURING}

With the help of nanoparticles, materials can be made lighter, stronger and more durable, more reactive, better electrical conductor etc. for example - Nanoscale additives used in polymer composite materials for tennis rackets, baseball bats, automobile bumpers, motorcycle helmets can make them strong, lightweight and long-lasting. Magnesium with dense ceramic $\mathrm{SiC}$ could be used to make lighter aeroplanes, spacecraft \& cars, helping to improve their efficiency hence making them energy saving. Structural metals are used in building \& vehicles such as magnesium which is $2 / 3$ the density of aluminum is the lightest structural metal (plasticity property). Silicon carbide (sic) is an ultra hard carbonic commonly used in industrial cutting blades. Silicate nanoparticles could slow down the process of drying out or spoiling in packaged food due their ability 
to provide barrier to gases or moisture. Silicon dioxide ( $\mathrm{SiO} 2)$ crystalline nanoparticles can be used in strengthening tennis racquets.

\section{NANOPARTICLES IN ENERGY \& ELECTRONICS}

Research is being done to generate more efficient \& cost effective energy. With the help of nanoparticles high efficiency light bulb can be produced. Plasmonic LED using peony containing carbon nanotubes, windmill blades are being developed. These nanotubes make blades stronger \& lighter which can boost the amount of electricity produced by individual wind mills. Nanotechnology use is involved in many different electronics, communication \& computing application providing faster, smaller \& more portable system. These system can store large amount of data, thus can increase storage capacity. Nanotechnology is used in smart cards, printed electronics and smart packaging as well as fiercible displays for book readers. Nanoparticles can be used in transistors to make them more powerful, faster \& highly efficient. Other uses of nanotechnology are next generation TV, plasma displays, digital cameras, organic light emitting diodes etc.

\section{NANOPARTICLES IN MEDICAL SCIENCE}

(a) Manipulation of cells and biomolecules can be one at nanoscale.

(b)Tissue engineering

(c) Tissue engineering

(d)Protein detection:- gold nanoparticles are extensively used in immunohistochemistry to detect interaction between proteins.

(e) Chemotherapy

In recent time, nanoparticles have emerged as key players in modern medicine. Their use in medicine is increasing due to their selective property. Nanoparticles are being used for directed or targeted drug \& gene delivery at tumor site. Polymer micelle nanoparticle is used to deliver drugs to tumors. Protem molecule with attached nanodiamonds can increase bone growth at required site. Chemotherapy drug is delivered to tumor cell in brain tumor.

A special dye is used in photo dynamic cancer therapy most of this dye is absorbed by cancer cells as compared to healthy cells. Therefore only the cancer cells destroyed. Polymer coated iron oxide for bacterial infection.

\section{CONCLUSIONS}

Nanoparticles are need of modern word to make their world more efficient. There are number of application in every field which can serve human race.

\section{SCOPE}

Besides number of application, still there are some to identify. Nanoparticles deals at nanoscale can enter human body \& can cause toxic effect in body $\&$ then their treatment is doubtful. So there are a lot of area left where research should be done to make them more useable. In future nanoparticles can help in making smart and efficient world and for this to happens scientist or researchers should be encouraged.

\section{REFERENCES}

[1] Abhilash, M. 2010, Potential application of nanoparticles. Int. J. Pharma Bio sci. 1 (1).

[2] Jens-Uwe, A., Junghanns, H., Rainer H. Muller 2008, nanocrystal technology, drug delivery and climical a pplication. Int. J. Nanomed., 3(3): 295-310.

[3] VarahalaraoVadlapudi, Kaladhar, D.S.V.G.K., Mohan Behara, sujatha, B., Kishore Naidu, G. 2013. Synthesis of green metallic nanoparticles and application. Orient. J..Chem 29 (4): 1589-1595.

[4] For details about nanoparticles introduction see the websitewww.nano.gov.

[5] Qin H4, Christopher Tuck, Ricky Wildman, and Richard Hagve;Handbook of nanoparticles, P 1219.

[6] Silicon carbide 2006 - Materials processing and devices. Vol. 911, ed. By M. Dudley, M. Capano, T.Kimono, A.R. Powell and sh. Wang (Mater. Res. Soc., Warrendale, 2006).

[7] Silicon carbide and Related Materials. EC SCRM 2006, vols. 556-557, ed. By N. Wright, CM. Johnson, K. Vassilevski, I. Nikitina and A. Horsfall (Trans. Tech Publ. mater. Sci. forum, Switzerland, 2007).

[8] R.A Andrievski, In: Nanomaterials handbook, ed by Y. Gogotsi (CRC Press: Boea Raton FL, 2006), P. 405

[9] H.Lin, J.A Gerbec,M. Sushchikh and E.W Mc Farland//nanotechnology 19 (2008) 325601-08.

[10] Baker, C., Hasanain, S.K and Shah, S.I. the magnetic behavior of iron onide passivated iron nanoparticles, J. Appl. Phys. $96,6657,2004$.

[11] K.A.D. Guzman, M.R Jaylor and J.F Banfield, environ. Sci. Technol,2006, 40, 140.

[12] C.L.chun, R.L. Penn and N.A. Arnod, Environ. Sci. Technol, 2006, 40,3299.

[13] M.Valacarcel, S. Cardenas, B.M. Simnot and Y. Moliner-Martinez,Trends, Anal. Chem., $2008,27,34$.

[14] J.L4, S. Yang. K.M. Ng, C.H S4, C.S Yeh, Y.N. wee and D.B Shied,Nanotechnology, 2006, $17,5812$.

[15] X. Peng, L. Manna, W. Yang. J. wickham, E, Scher, A.Kadavanich and A.P Alivisatos, Nature, $2000,404,59$.

[16] Williord, M.A., kurihara, L.; carpenter, E.E., Colirn, S., Harmis V.G Encyclopedia of nanoscience \& Nanotechnology; Nalwa H.S., Ed., American scientific publishers; Valencia, ca, 2004; vol. 1. P815.

[17] Basak, S., chen, D. -R; Biswas, P, chem. Eng. Sci 2007, 62, 1263. 
[18] Pal, sovancal, pal, pal, Manna, P.K; Mohanta, G.P.\&Manavalan, R., 2011 "nanoparticle: an overeview of preparation \& characterization" J. 06 pharmacentical sci., vol. 116 pp 228-334.

[19] Chang, W., Skandan, G., Hahn, H., Dangorth, S.C and kear B.H., 1994 "Chenical condensation of nanostructured ceramic powders",nanostructured material, vol 4 (3), pp 345-351.

[20] Winterer, M. and Hahn, H., metallkd, Z., 2003 chemialvapour synthesis of nanocrystal powders. Nanoceramices by chemical vapour synthesis vol. 94, pp (1084-1090).

[21] K.S. Suslick, M. Fang and T. Hyeon, J.am chem. Soc. 1996, 118, 11960

[22] C.T. Black, C.B, Murray, R.L Sandstrom\& S. Sun, science 2000, 290,1131.

[23] C.li4, B. Zou, A.J. Rondinone\& Z.J. Zhang. J. Am. Chem.. Soc., 2000,122 6263.

[24] Scherer gov, brinker c. sol- gel science. The physics \& chemistry of sol-gelprocessing, Jeffery (ed). Academic press: andiego 1990.

[25] Schmidt H, Nonninger R. procudings of fine ultra fine\&nano powders 98, New York, 1998.

[26] Siegel RW. Nanometer: syrth. Prop, appe 1996; 201-218.

[27] Asta, susan M. Kauzlarich, Kai liu, AlezandraNavrotsky, frank, E 2007 osterloh inorganic nanoparticles unique properties \& novel application.Mater, matters, 2 (1).

[28] Wimhed Jong. Paul JA Borm 2008. Drug delivery and nanoparticles: applications \& Hazards. Int. J. Nanomedi 3 (2) : 133-149.

[29] N.IRosi, D. A Giljohann, C. S Thaxton, A.K.R lytton jean, M. S Han and c.a mirk in science 312, 11027,. 2006

[30] T. Masciangioli\& W.X Zhang. Environ. Sci technol. 36. 102 A 2003

[31] Bcc Research, Nanotechnology in nvironmental Application (RNANO39A)

[32] J cao, D.W Elliott, and W. Zhang. J Nanopart. Res 7, 4992005.

[33] X4, A. Dozier, and D. Bhattacharya J. Nanopart. Res 7, 4492005.

[34] K. sohn, S.W. Kang, S. Shn, M. woo, and S.K yang, environ. Sci technol. 40, 55142006.

[35] F. X red, k.s. cho, c.bmurray, s.ogrien. Nature 2003, 423, 968 (xxxviii) H. y4 m mchen, D. M rice, s.x. wang. R.L white, /s.H. sun ,nano let. $2005,379$.

[36] J. Li, h. zeng, SH. Sun J.P Liu Z.L wang J physl them B 2004 108,14005.

[37] M. Shimada, n shoji and A. Takacashi, anticancer res, 1995, 15, 109.

[38] P. Tartaj. In encyclopedis of nanoscience and nanotechnology, vol. 1, H.S nalwa , P - 177 American scientific publishes, Stevenson Ranch , CA12004.

[39] Y.W jun, J. S choi, J. cheon, chem., commum. 2007, 203

[40] Jli,H, zeng. S. H. sun, J.P ku4m z,k, wabg H, phys, chem.. B 2004, 108,14005

[41] Yan $\mathrm{H}<$ liQ, Zhang J \& li4 Z 2002 carbon lio 2693-8.

[42] Passler P Hefner W \&wernicke H- J 1985 uimann'seneyclopedia of industrial chemistry vol a weindeimvch pp 99-145.

[43] Johnson, T. L. Scherer, M.M and organic tratnyedk, P.G kinetics of halogenated organic compounds degradation by iron metal en ciron sci. technol-30, 2634, 1996.

[44] Kanel, S. R manning B., Charlet 1., and chei, h., removal of arsenic from groundwater by nanoscale zerovalent iron environ scitechnol 39, $1291,2005$.

[45] C.L chunm R.L. penn and W. A aronld, evnronscitechnil 2006,40, 3299.

[46] G.Z. Cao, nanostructure and nanomaterials, synthesis properties and application, London imperial college press pp 329, 2004.

[47] N. savage and M.S diallo, j. nanopart. Res, 2005 , 7, 331.

[48] Prasad rao, J; Kurt geckeler, E. 2011 polymer nanopartice preparation techniques \& size control parameters prog. Polymer sci, 36 (7); $887-913$. 